\title{
Quality Management of Educational Activities in the Training of Specialists in the Field of Health Care: the Case of Ukrainian Medical HEIs
}

\author{
Svitlana V. Gordiichuk \\ Zhytomyr Medical Institute of Zhytomyr Regional Council, Zhytomyr, Ukraine \\ https://orcid.org/0000-0003-4609-7613 \\ Liudmyla M. Kalinina \\ Institute of Pedagogy of the National Academy of Pedagogical Sciences, Kyiv, \\ Ukraine \\ https:// orcid.org/0000-0003-0534-6089 \\ Irena E. Snikhovska \\ Zhytomyr Ivan Franko State University, Zhytomyr, Ukraine \\ https://orcid.org/0000-0001-6775-274X \\ Olga V. Goray \\ Zhytomyr Medical Institute of Zhytomyr Regional Council, Zhytomyr, Ukraine \\ https://orcid.org/0000-0002-2389-1366
}

\begin{abstract}
The paper addresses the current background, shortcomings and improvement perspectives for the quality management system in training nurses, paramedics and midwives in HEIs of Ukraine. To reach the aim of the study, the authors analysed the legal and regulatory documents, website documentation and electronic resources of 23 medical HEIs. The methods of mathematical data processing and criterion analysis were used to analyze the effectiveness of the quality management system implementation medical HEIs. The survey of the managerial and administrative staff $(n=398)$ was conducted. The aim of the survey was to gain insight into the internal quality management principles and procedures in medical higher educational institutions of Ukraine, to identify the main tools used for internal auditing of educational quality, the measures taken to assess the education quality at the institutional level. The research findings are discussed with due regard to the surveyed managerial staff needs and quality assurance guidelines in medical education. The results of the article have a few significant implications for practice of quality management system in medical colleges and its perspectives for enhancing Ukrainian higher education system. The conclusion was made that with introducing an effective quality management system in medical HEIs, continuous monitoring of quality assurance by HEI leaders, commitment to quality
\end{abstract}


as an organizing factor in education management, future medical specialists will be competitive, demonstrating a sustainable growth in academic performance, developing relevant practical skills and professional mindset.

Keywords: Quality management; Quality assurance; Medical higher education institution; Total quality management; Competence

\section{Introduction}

In this article, we shall probe into QM practices in Ukrainian medical HEIs. This study aims to substantiate the rationale for the current background and improvement perspectives for the quality management in training nurses, paramedics and midwives in HEIs of Ukraine in connection with the shift of the education paradigm to instill the culture of quality. We shall highlight the premises and goals of the QMS at medical HEIs in Ukraine and illuminate the insight of its implementation drawing on the authors' model of the QMS of educational activity. The findings should help HEI leaders pursue the idea of quality awareness and develop the framework for quality management in their department, college, institute, or university.

Currentlly, we witness an unprecedented drive for innovation and quality in education worldwide, an urgent need to enhance the competitive advantage of higher education institutions (HEIs). The effective Strategic Program for European Cooperation in Education "Education and Training 2020" directs EU member states to create high-quality lifelong national education systems for the varied population segments. Quality education underpins the development of sustainable societies and personal development, professional careers and safeguards against unemployment and poverty. In the European context, this will not only contribute to the EU's economic and social goals, but will have a positive impact on its member states' socio-oriented capital. The outlined problem has a priority social significance as evidenced by the pandemic on a global scale, and undoubtedly is relevant for Ukraine and for all countries without exception.

According to world practice, one of the most effective methodologies for achieving this goal is the use of total quality management (TQM), which includes a set of strategies. In this regard, the category of quality of medical education is decisive as a result of quality management of educational activities in the training of specialists in the field of health care. The strategy for the development of quality higher medical education in Ukraine draws on global and European trends to enhance its essence, mechanisms and results of its acquisition, which in many countries has become the basis for a resilient nation and accelerator of their economic prosperity. Ukrainian researchers are well aware and take account of the international experimental studies conducted worldwide, in particular the correlation between the level of the national education system and the competitiveness of the country, thus the need to pursue high-quality higher education (including medical education) is obvious. Morover, given the falling of Ukraine's position in international rankings, in 
particular the Human Development Index, the Freedom of Education Index (Miller et al., 2020), the Global competitiveness Index, etc., the quality of Ukrainian higher education should become an organizing factor.

The recent years have witnessed a surge of efforts to upgrade educational services in Ukraine to international standards of excellence. According to Ukraine's legislative documents, the National Agency for Higher Education Quality Assurance (NAQA) is responsible for setting out requirements for quality and transparency for institutions, programs, and standards, implements state policy in the field of higher education and withstands modern challenges. To actualize these priorities and the ESG-2015 standards developed within the frame of the Bologna Process (Bologna Process Implementation Report, 2018; ESG, 2015) as well as European best practices [QUAERE, 2018a; QUAERE, 2018a], NAQA has developed the Regulation on Study Programs Accreditation (Regulations, 2019) and it was adopted in August 2019 by the Ukrainian Cabinet of Ministers.

The procedure of the new study programs accreditation began in September 2019 and is currently in progress, carried out by the NAQA experts. The establishment of the National Agency was an important stage in the reform of Ukrainian higher education, aimed at aligning the accreditation procedure with that of the European higher education and research area (EHEA), developing quality assurance system at both national and institutional levels (Strategy, 2020). NAQA is performing some of the key powers of the Ministry of Education and Science of Ukraine. The first role of NAQA is viability analysis of the study programs at higher educational institutions, responsibility for their evaluation and accreditation according to measured criteria, issuing a relevant opinion and recommending measures for improvement, etc. Apart from that, the institutional accreditation and accreditation of independent accreditation agencies are an essential function of NAQA, as well as promoting academic integrity, ensuring transparency in university rankings, fostering internal quality assurance of Ukrainian universities (Sydorenko, 2016). In the renewed accreditation process, the ability of higher education institutions to provide a quality teaching and learning process based on the principles of university autonomy is studied and evaluated (Stukalo \& Dluhopolsky, 2020).

The purpose of this study was to determine the state of the quality management system of educational activities in the training of specialists in the field of health care in Ukraine during 2014-2019 and to monitor the implementation of the quality management system among medical HEIs training future nurses, midwives, paramedics. To reach the aim of the study, the authors analysed the legal and regulatory documents, website quality management documentation and electronic resources of 23 medical public HEIs.

The hypothesis of the study was as follows: the competitiveness of the healthcare professionals depends on the quality of educational activities of the institution of higher learning and the level of formation of general and special competencies. Competence is viewed as a basis for the preparedness acquired in 
the process of professional training in the field of health care, as well as a component of quality medical education. The data used for the study to test the hypothesis were obtained through questionnaire sent to the management staff of medical HEIs in Ukraine. The hypothesized relationships were tested with data collected from 356 respondents by using the Spearman's rank correlation method.

\section{Literature review}

In this section, the international scope of the quality management philosophy is highlighted, as well as the quality assurance context in Ukraine is outlined. Extensively used in business, manufacturing and services, the total quality management (TQM) methodology provides effective tools to manage change in education (Sallis, 2015) to produce educational services in the best, effective and efficient manner by way of enhancing managerial control over HEI quality assurance (Lubwama, Onen, \& Kasenene, 2017). Exemplifying the Greek case, Psomas and Antony (2017) emphasize that all educational activities should be aimed at ensuring excellent academic performance, while HE quality management must arise from the entire academic community awareness. Exploring TQM in emerging economies, London argues that in managing for quality, an achievement-raising factor the concept of quality itself may be reconceptualized as a way of enforcing the QM practices and strategies to be adopted for effective management (London, 2006). As Sciarelli et al. show, to implement QM properly and achieve its effectiveness, HEIs shoud establish both soft and hard QM practices, adopting the multidimensional approach of QM in HE which could help directors understand the interdependencies of soft and hard quality practices (Sciarelli et al., 2020).

An important point is made by Tarí and Dick (2016) regarding the trends in quality management research at HEI. In particular, the authors make efforts at a thorough analysis to show that the indispensable prerequisites for high quality in higher education are a long-term planning, formulating yearly quality programs and executing such quality programs to the letter annually so that the vision of the higher education institutions can be accomplished. The implementation of TQM practices is viewed as a crucial factor in reviving HEI by way of entrenching awareness about quality into all undertaken procedures (Johnson, 2019). According to Karuppusami and Gandhinathan, critical success factors present essential constructs proceeding from the statistical analysis can be carried out further to guide the researchers in using the reliable set of factors for empirical studies (Karuppusami \& Gandhinathan, 2006). To this end, Tarî and Dick identify several critical success factors, namely: organizational management, communication as a means of enhancing quality, the involvement, training and professional development of the employees, and university recognition and culture. All these must be given proper consideration by HEI before total quality can be achieved or become successful (Oluwafemi \& Laseinde, 2020). Also, in our research we take account of the literature review done by Sila and Ebrahimpour, who identified twenty five critical success factors of TQM based on survey studies conducted in different countries and published in a variety of journals (Sila \& Ebrahimpour, 2002). 
In the European Association for Quality Assurance Agencies context, accreditation of the study programs includes some institutional elements, such as the functioning of the internal quality assurance system, objectivized with due regard to a robust and reliable education management system to ensure the quality of provided educational services (Al-Ababneh \& Alrhaimi, 2020; Sari, Hadiyat, \& Beatrice, 2015).

However, in medical HEIs there are numerous concerns as regards the stage-bystage integrated learning outcomes framework, assessment mechanisms (Macha, 2018). As Cumming (2010) notes, "application of the Bologna principles to medicine can help to drive educational development and quality enhancement in European medical education". Patrício and Harden (2010) argue that medical education in the Bologna Process serves as a catalyst for necessary changes.

The overview of management practices in Ukrainian medical HEIs convincingly demonstrates the drive to the strategic and information management, quality assurance system development at the institutional level and their efficient practical implementation (Mazurkiewicz, Liuta \& Kyrychenko, 2017; Kovtun \& Stick, 2009). To achieve this goal, a TQM methodology in higher education has been introduced (Knutson \& Kushnarenko, 2015). The institutional policy and mission on education quality as well as the procedures and tools, progress controls and performance indicators (European Standards and Guidelines, 2015; EHEA Report, 2018 Bucharest Communique, 2012) of internal QA system of education are being elaborated in Ukraine (Kuruch, 2018;Gordiichuk, 2018;Gordiichuk, 2019a, Mazurkiewicz, 2016; Finikov, 2018).

In Ukrainian medical colleges and schools, after their transition to a system of professional pre-university education, efforts are made to create more integrated reinforced curricula similar to those at the European medical schools, however the model is currently under construction and has yielded no feasible results yet (Kondrashov, 2018). That is why the creation of a QMS for educational activities at the medical college has become urgent in recent years (Gordiichuk, 2017). In Ukrainian context, the evaluation approach based on QA is used, and the prerequisite of QMS is paramount to understand for an effective operation in the sphere of higher education in Ukraine (Bilokonenko, 2018).

It is grounbreaking that NAQA has achieved international recognition through a full membership in the International Network for Quality Assurance Agencies in Higher Education (INQAAHE), affiliation with the European Association for Quality Assurance Agencies (ENQA) and was included in the relevant list of the European Quality Assurance Register for Higher Education (EQAR). It gives every reason to consider the approaches towards accreditation in Ukraine to be consistent with the requirements common in European practice.

\section{Methodology}

At the level of methodology, the subject of consideration is the managerial activities of medical HEIs in Ukraine to ensure quality medical education. The systemic analysis in higher medical education also requires: policy and mission 
of the institution to ensure quality education, organizational structure of quality management of educational activities; procedures, tools, success factors and indicators of effectiveness.

The study was a succession of three stages: Stage 1 (the initial stage), Stage 2 (the intermediate stage), and Stage 3 (the final stage). At different stages of the research the following methods were used to address the tasks set: Stage 1: theoretical analysis of literature, content analysis of the basic concepts, synthesis and summation of the relevant normative and legal documents in EHEA regulating the quality management of educational activity were carried out, as well as drawing on the relevant research done by the European scholars Wibisono (2018), Camilleri (2017), Fonseca (2015) and Ukrainian researchers Kovtun and Stick (2009). Also, modeling was performed at this stage to develop a framework for the survey of medical HEIs; Stage 2: empirical observations, questionnaires, testing to determine the indicators for the model, experimental survey to test the effectiveness of the authors' method of quality management; Stage 3: prognostic - independent expert evaluations for the purpose of implementation and approbation of the developed criteria for assessing quality; and statistical - methods of mathematical processing of quantitative research data. In this study we focused on the effectiveness of the health care specialists training using Spearman's rank correlation method, which allowed determining the strength and correlation direction between the formed competencies in academic disciplines and methods of mathematical processing of the data set on the rank correlation coefficients.

At the initial stage of the research, the unit of analysis was taken to be the educational achievements of medical students, which they obtained by mastering basic disciplines. At the intermediate stage of the study, the unit of analysis was the relation between performance in basic and fundamental disciplines. At the final stage after the introduction of the content of education, the unit of analysis was the formation level of professional competencies in medical education.

To address the existing state of implementing the quality management system of educational activities in medical HEIs, a survey of the managerial and administrative staff was conducted on the principles and procedures of the quality assurance system of educational activities at the institutional level. The total number of respondents was 398, including 23 rectors of medical colleges, 63 vice-rectors, 89 heads of departments, 24 experts in teaching methodology and 199 chairpersons of final examination boards. The main sample inclusion criterion was to be a representative of a medical HEI. The questionnaire used for the study was a modification for medical institutions of a questionnaire developed by the International Charitable Foundation "International Foundation for Educational Policy Research" which the Ukrainian Catholic University conducted within the framework of the project "Educational Initiatives Space" (Finikov and Tereshchuk, 2018). The questionnaire took into account the specifics of medical colleges and management of educational activities, training of specialists in health care. 
The survey (Appendix 1) comprised 28 questions, which were subdivided into three clusters and provided for selective, constructive and alternative answers. The first cluster aimed at collecting the general information on HEI, its teaching staff, the availability of structural units responsible for the implementation of the internal quality management system of educational activities at the medical institution of higher learning. The questions of the second cluster made it possible to gain insight into the presence of the internal quality assurance system in medical HEIs, the main tools used for internal auditing of educational quality, the measures taken to assess the education quality in medical HEIs. The third cluster included the questions that determined the feedback from the main stakeholders.

The second objective of the intermediate stage of the study was to analyze the relevant information and the data on quality management of educational activities, available on the official websites of higher medical education institutions participating in the survey. Further, a comparative analysis yielded the results about the actual state of implementing the internal quality management system in medical institutions as compared with the data provided by the medical colleges' management. In total, the structure and content of the official webpages of 23 medical schools and colleges throughout Ukraine were analyzed.

The conceptual component of the authors'model allowed implementing the concept of the overall quality management of educational activities in medical educational institutions. The methodological and fit-for-purpose component of the quality assurance system of educational activities in medical educational institutions provided for the formation of strategy as well as strategic and tactical goals and objectives of quality assurance of educational activities in medical colleges. The subjective and contentual component of the model ensured a quality management of the educational activities in the medical college on the basis of national educational standards and quality management system. The activity and procedural component of the model made it possible to gain insight into the compliance of educational services provision by the medical institution of higher learning with licensing and accreditation requirements in higher education and a reasonable provision of resources for the teaching and learning process. This component of the model was considered from the standpoint of system management in terms of the quality assurance using the system-based, the process-based, the situation-based, the innovative, the informational, the competency-based, the resource, the creative, and the standardized approaches, as well as relying heavily on internationalization and academic integrity. In its turn, the evaluational component of the system of quality assurance of educational activities of the medical college provides for an analysis of the effectiveness of the quality of educational activities of the medical college and the quality level of medical education.

To analyze the effectiveness of the quality management system of educational activities in medical colleges, the academic performance of the degree-seeking students in medical education during their programme's life cycle from 2014 to 
2019 in 4 medical colleges was analyzed, in particular: Zhytomyr Medical Institute, Berdychiv Medical College, Mykolayiv Basic Medical College and Vinnytsia Medical College named after acad. D.K. Zabolotny. Basically, the key indicators taken account of in the study were as follows. Indicator 1: The prospective students' success in the subject of biology as a major discipline when entering the medical college, as attested by the completion certificate of the basic general secondary education or the certificate of complete general secondary education; Indicator 2: The prospective students' success rate in the subject of biology of based on the results of entrance examinations (for persons who were enrolled on the ground of the basic general secondary education) and the results of external independent evaluation (for persons who were enrolled on the ground of the basic general secondary education); Indicator 3: The students' success rate in fundamental disciplines: "Human Anatomy", "Physiology", "Medical Biology", "Fundamentals of Medical Genetics" belonging to the cycle of general training; Indicator 4: The students' success rate in professionallyoriented disciplines (majors): "Internal Medicine", "Surgery", "Pediatrics", "Obstetrics", "Gynecology", "Nursing in Internal Medicine", "Nursing in Surgery", "Nursing in Pediatrics" "Nursing in obstetrics", "Nursing in gynecology". Indicator 5: The undergraduate students' success rate in passing the mid-tests both in the subject cluster "Internal Medicine", "Surgery", "Fundamentals of Nursing" and "Patient Care", "Pediatrics", "Obstetrics and Gynecology" within the framework of the national integrated exam KROK-M.

In total, in the course of the final stage of the study, the academic performance of 895 students was analyzed, including 284 students who were enrolled in the medical college on the ground of the basic general secondary education (111 people studied at the department "General Medicine", the qualification of a paramedic; 173 people - at the department of "Nursing", the qualification of a nurse), and 611 people who entered the program on the score of complete general secondary education (246 people studied at the department "General Medicine", the qualification of a paramedic, 206 people - at the department "Nursing", the qualification of a nurse; 159 people - at the department "Obstetrics", the qualification of a midwife).

To explore the effectiveness of the quality management system of educational activities in medical colleges, the success rates of each student in the course of their educational life cycle were compared by determining the Spearman correlation coefficient (the direct and inverse strong correlations $\pm 0.1- \pm 0.29$, average strength $\pm 0.3- \pm 0.69$, weak $\pm 0,7- \pm 0.99, \pm 1$ complete dependence) The reliability of the received results was verified by means of Student's criterion. Due to the methodology used in our empirical analysis it should be emphasized that the following findings reflect the relevance of quality assurance management in medical HEIs.

\section{Results}

Based on these findings, further conclusions can be drawn. In the course of the research, we determined that the management of 23 medical schools and colleges claims to have its own internal system for quality assurance of 
educational activities and the implementation of procedures and measures provided for by the regulatory documents. At the same time, the heads of medical HEIs that took part in the survey noted that at the institutional level there are only elements of internal quality assurance systems for educational activities. Moreover, rectors ad vice-rectors of 22 medical schools and colleges expressed their intention to build local quality assurance systems. In our opinion, the resulting imbalance of answers is associated with a lack of awareness, motivation, interest in the need to implement internal QA system to ensure the quality of educational activities by the top management of medical HEIs.

According to the research data, it was shown that in all the surveyed medical HEIs there is no separate structural units responsible for the management and quality assurance of educational activities. The structural units that are in charge of periodical monitoring of the quality of educational services are as follows: the Department of Teaching and Learning, the Department of Practice, the Final Exams Commission, and administrative officials (Vice-Rectors for Educational Work, heads of departments, the chairpersons of final examboards, experts in methodology, etc.).

The management of medical education institutions uses various audit methods and plans measures to eliminate the identified shortcomings, clarifies problematic issues, but does not take into account the results of self-assessment of their own activities by teachers. The heads of medical schools and colleges unanimously agree as regards the necessity for consistent review of educational programs. For a qualitative revision and correction of the content of the educational program, the opinions of stakeholders are monotored: teaching staff (52.2\%); HEIs administration (43.5\%); students' parents (56.6\%); employers (39.2\%); students (34.8\%); professional public associations, unions (30.5\%), entrants $(13.1 \%)$. Notably, analyzing the respondents' answers to the measures taken as a result of the review of educational programs, we found that the removal of unnecessary subjects is systematically or periodically carried out in $21 \%$ of institutions; $26 \%$ of medical colleges and schools introduce the new compulsory subjects based on the results of the audit; $78 \%$ transfer disciplines to another year of study; 39\% expand the list of the student's elective disciplines; $47 \%$ develop new educational programs.

\section{Discussion}

One of the problematic issues of procedures and measures to ensure the quality of educational activities is to assess the quality of teachers' work. The basic measures taken during the audit of the teaching staff activities at medical HEIs are as follows: the use of systematic or periodic surveys of students on the quality of teaching (91\%); conducting open lectures with their subsequent evaluation by the colleagues and administrators (95\%); conducting the final control in the discipline (test / exam) by another teacher (73\%); executing the rector's test papers (94\%); monitoring the volume and quality of the educational and methodological support of the discipline developed by the teacher (textbooks/manuals, workshops, tests, etc.) (92\%); evaluation of the teacher's 
research activity (number of publications, participation in scientific conferences, etc.) on quality assurance of education (90\%); assessment of the teacher's extracurricular activity (arranging academic competitions and contests, supervising students' reserch, etc.) (93\%). Thus, the management of medical HEIs with different degree of frequency (systematically/periodically) tries to audit the teachers' educational, methodological, practical, educational, scientific activities.

Of a particular concern is consistency and systemic character in the use of information obtained during the audit to improve the quality of educational activities, as we found the following frequency of measures based on the results of teaching quality assessment: an personal interview with the head of medical institution (systematically 69.5\%, periodically 21.7\%), formation and making public the teachers' rankings of HEIs based on the results of the teaching quality audit (systematically $34.9 \%$, periodically $47.9 \%$ ); the salary differentiation depending on the results of the audit of the teaching quality (systematically $17.3 \%$, periodically $8.9 \%$ ); introducing financial incentives in the form of awarding the best performing teachers based on the results of the audit of the teaching quality in medical schools and colleges (systematically 52.1\%, periodically $34.7 \%$ ); mandatory teacher's certification at the advanced training courses, extention courses, etc. based on the results of the audit of the teaching quality in medical HEIs (systematically $60.8 \%$, periodically $8.7 \%$ ); dismissal of teachers based on the results of the audit of the teaching quality in medical schools and colleges (systematically $4.5 \%$, periodically $13 \%$ ). Thus, as a rule, the main incentives to increase the motivation and quality of teaching are financial rewards, while in the identification of shortcomings in teaching and learning process the management of medical HEIs focuses only on individual interviews and recommendations for the training enhancement (Gordiichuk, 2019).

In our opinion, one of the criteria for the effectiveness of the internal quality assurance system of educational activities is the extent to which the general and special competencies in medical education are formed. We also found out what the tools are and how often they are implemented to audit learning outcomes. Thus, it is determined that $86 \%$ of medical colleges and schools systematically carry out internal measurement of the competence formation level by conducting rector's tests, internal testing and review procedures, etc.; $47.8 \%$ of medical HEIs systematically and $30.4 \%$ periodically conduct external evaluation of the quality of students learning outcomes; $43.4 \%$ of the surveyed medical HEIs conduct surveys of graduates and maintain feedback with them; the top management of $30.4 \%$ of medical colleges and schools systematically and $56.5 \%$ periodically conduct surveys among the employers (enterprises, institutions, etc.) in order to obtain an assessment on the alumni employees' skills, abilities, knowledge quality.

The subsequent part of the study was to analyze the completeness of the published information on the HEIs official websites. The criteria for the analysis were as follows: the availability of regulatory documents (an organization charter, a corporate agreement, information on the activities of structural units, 
provisions on the organization of the educational process, regulations on the internal quality assurance of educational activities, information on degree programs and relevant study programs offered in medical HEI; the details as regards the admission and enrollment, etc.); information about the department or structural unit in charge of monitoring the quality of education; interaction with stakeholders; the results of the annual surveys of students and teaching staff; information on the conducting of educational activities at medical education institutions.

The information published on the official websites of medical HEIs basically highlights the history of the institution, the composition of the administration, departments as structural units of medical institutions, cycle subject commissions as structural units responsible for methodological activities, licensing and accreditation, enrollment, etc. The websites of $17 \%$ medical schools and colleges do not provide any information about the organization charter, the corporate agreement, internal provisions regulating teaching and learning, methodological, educational, practical and scientific activities. Only a scanned copy of the regulations on the educational process is posted on the official websites of 15 medical education institutions (65\%). In our perspective, the following aspects are particularly striking and presented a challenge for the objective dta collection. Analyzing the official websites of 23 medical HEIs that train nurses, midwives, paramedics, we found that only the websites of the two of them $(8.5 \%)$ published the provisions on the internal quality assurance system, the websites of still two more medical colleges and two medical schools $(17.3 \%)$ contain provisions on internal control, on internal school control, on monitoring the quality of the educational process, on conducting rector's tests, which is an element of the internal quality assurance system of education. No medical education institution has a separate structural unit responsible for quality assurance. Moreover, there was no information in terms of feedback from health care institutions in charge of internship training, nor stakeholders (employers, students and their parents, alumni, etc.). Furthermore, we did not find any ratings assessing the educational activities of the HEI teaching staff (in one institution of medical education there was a provision in place on the rating of teachers, the website of another institution contained information on the regulations of preparation for certification of teachers). The websites of 12 medical schools and colleges (52\%) provided the documents informing about educational programs for training students on the basis of both complete and basic general secondary education.

Analysis of the effectiveness of the implementation of the quality assurance system of educational activities in the Zhytomyr Medical Institute" revealed the presence of strong direct correlations at the Departments of the General Medicine, the Department of Nursing and the Department of Obstetrics (Table 1): 
Table 1: Correlation between performance, of competence formation level and medical education quality in Zhytomyr Medical Institute

\begin{tabular}{|c|c|c|c|}
\hline Department & Discipline & $\begin{array}{l}\text { Competencies formed } \\
\text { by the discipline }\end{array}$ & $\begin{array}{c}\text { Correlation } \\
\text { strength }\end{array}$ \\
\hline \multirow{8}{*}{$\begin{array}{l}\text { General } \\
\text { Medicine }\end{array}$} & \multirow{3}{*}{ Human Anatomy } & Internal Medicine & 0.77 \\
\hline & & Surgery & 0.76 \\
\hline & & Gynecology & 0.77 \\
\hline & \multirow{2}{*}{$\begin{array}{l}\text { Pharmacology and } \\
\text { Medical Prescription }\end{array}$} & Internal Medicine & 0.73 \\
\hline & & Obstetrics & 0.75 \\
\hline & Infectology & Microbiology & 0.75 \\
\hline & \multirow{2}{*}{ Patient Care } & Internal Medicine & 0.76 \\
\hline & & Gynecology & 0.72 \\
\hline \multirow[t]{6}{*}{ Nursing } & \multirow{3}{*}{ Human Anatomy } & Nursing in Pediatrics & 0.78 \\
\hline & & Nursing in Surgery & 0.85 \\
\hline & & Nursing in Gynecology & 0.73 \\
\hline & \multirow{2}{*}{$\begin{array}{l}\text { Pharmacology and } \\
\text { Medical Prescription }\end{array}$} & Nursing in Surgery & 0.79 \\
\hline & & Nursing in Pediatrics & 0.77 \\
\hline & Fundamentals of Nursing & Nursing in Obstetrics & 0.75 \\
\hline Obstetrics & $\begin{array}{l}\text { Pharmacology and } \\
\text { Medical Prescription }\end{array}$ & Gynecology & 0.86 \\
\hline
\end{tabular}

A comparative analysis of other indicators revealed the presence of direct correlations of the average strength between the studied phenomena in students of the three departments. The analysis of the results of student success in the life cycle in Berdychiv Medical College at the Department of General Medicine, the Department of Nursing gave an opportunity to establish strong direct correlations between competencies formed by general training in the disciplines and students' competencies in the fundamental disciplines (Table 2):

Table 2: Correlation between performance, of competence formation level and medical education quality in Berdychiv Medical College

\begin{tabular}{|c|c|c|c|}
\hline Department & Discipline & $\begin{array}{c}\text { Competencies formed by } \\
\text { the discipline }\end{array}$ & $\begin{array}{c}\text { Correlation } \\
\text { strength }\end{array}$ \\
\hline \multirow[t]{4}{*}{ General Medicine } & \multirow{2}{*}{ Biology } & Human Anatomy & 0.72 \\
\hline & & Surgery & 0.76 \\
\hline & \multirow{2}{*}{ Human Anatomy } & Internal Medicine & 0.77 \\
\hline & & Surgery & 0.70 \\
\hline \multirow[t]{8}{*}{ Nursing } & \multirow{2}{*}{ Biology } & Human Anatomy & 0.70 \\
\hline & & Medical Biology & 0.77 \\
\hline & Human Anatomy & Nursing in Pediatrics & 0.90 \\
\hline & $\begin{array}{l}\text { Pharmacology and } \\
\text { Medical Prescription }\end{array}$ & Nursing in Gynecology & 0.76 \\
\hline & \multirow{3}{*}{ Physiology } & Nursing in Pediatrics & 0.90 \\
\hline & & Nursing in Obstetrics & 0.75 \\
\hline & & Nursing in Gynecology & 0.81 \\
\hline & Biology & $\begin{array}{l}\text { Nursing in } \\
\text { Medicine }\end{array}$ & 0.72 \\
\hline
\end{tabular}

The comparative analysis of student performance based on the implementation of the model of quality assurance of educational activities at the Department of 
General Medicine, the Department of Nursing, the Department of Obstetrics at Mykolayiv Basic Medical College yielded strong correlations between competencies formed by the fundamental disciplines (Table 3):

Table 3: Correlation between performance, of competence formation level and medical education quality in Mykolayiv Basic Medical College

\begin{tabular}{|c|l|l|l|}
\hline Department & \multicolumn{1}{|c|}{ Discipline } & $\begin{array}{l}\text { Competencies formed } \\
\text { by the discipline }\end{array}$ & $\begin{array}{c}\text { Correlation } \\
\text { strength }\end{array}$ \\
\hline General Medicine & General Care & Gynecology & 0.74 \\
\cline { 2 - 4 } & $\begin{array}{l}\text { Pharmacology and } \\
\text { Medical Prescription }\end{array}$ & Gynecology & 0.74 \\
\cline { 2 - 4 } & Pediatrics & 0.73 \\
\hline \multirow{2}{*}{ Nursing } & Biology & Medical Biology & 0.76 \\
\cline { 2 - 4 } & Human Anatomy & 0.74 \\
\cline { 2 - 4 } & Human Anatomy & $\begin{array}{l}\text { Nursing in Internal } \\
\text { Medicine }\end{array}$ & 0.73 \\
\cline { 2 - 4 } & Nursing in Pediatrics & 0.76 \\
\cline { 2 - 4 } & $\begin{array}{l}\text { Pharmacology and } \\
\text { Medical Prescription }\end{array}$ & Nursing in Obstetrics & 0.72 \\
\hline \multirow{2}{*}{ Obstetrics } & $\begin{array}{l}\text { Pharmacology and } \\
\text { Medical Prescription }\end{array}$ & Surgery & 0.76 \\
\cline { 2 - 4 } & General Care & Obstetrics & 0.79 \\
\hline
\end{tabular}

Analysis of efficiency indicators of introducing the system of quality assurance at Vinnytsia medical college named after acad. D.K. Zabolotny enabled to reveal that the educational achievements of medical students who studied at the Department of General Medicine, the Department of Nursing, the Department of Obstetrics showed strong direct correlations between the competencies formed at the level of general education disciplines and the competencies formed at the level of professionally-oriented clinical disciplines (Table 4):

Table 4: Correlation between performance, of competence formation level and medical education quality in Vinnytsia medical college named after acad. D.K. Zabolotny

\begin{tabular}{|c|l|l|l|}
\hline Department & \multicolumn{1}{|c|}{ Discipline } & $\begin{array}{l}\text { Competencies formed } \\
\text { by the discipline }\end{array}$ & \multicolumn{1}{c|}{$\begin{array}{c}\text { Correlation } \\
\text { strength }\end{array}$} \\
\hline General Medicine & Biology & Medical Biology & 0.73 \\
\cline { 2 - 4 } & Human Anatomy & Gynecology & 0.71 \\
\hline \multirow{3}{*}{ Nursing } & Human Anatomy & Nursing in Pediatrics & 0.73 \\
\cline { 2 - 4 } & $\begin{array}{l}\text { Nursing in Internal } \\
\text { Medicine }\end{array}$ & 0.73 \\
\cline { 2 - 4 } & $\begin{array}{l}\text { Pharmacology and } \\
\text { Medical Prescription }\end{array}$ & Nursing in Obstetrics & 0.73 \\
\cline { 2 - 4 } & Physiology & Nursing in Pediatrics & 0.73 \\
\hline Obstetrics & $\begin{array}{l}\text { Pharmacology and } \\
\text { Medical Prescription }\end{array}$ & Pediatrics & 0.74 \\
\cline { 2 - 4 } & Physiology & Internal Medicine & 0.71 \\
\cline { 2 - 4 } & Patient Care & Obstetrics & 0.74 \\
\hline
\end{tabular}

Among other indicators analyzed, in the departments where the training of future paramedics, midwives, nurses is provided, should be mentioned the 
presence of direct orientation correlations of medium $(86 \%)$ and weak (2\%) strength.

Thus, based on the results of the study, we have drawn some inferences about the state of implementation of quality assurance in Ukrainian medical HEIs. The management of medical schools and colleges only declares the implementation of an internal quality assurance system or its elements, but a detailed analysis drawing on the answers of respondents and monitoring of official websites shows that most medical HEIs do not have the necessary information, methodological, incentive and human resources to implement effective quality assurance system at the institutional level.

In the medical HEIs that participated in the study, there are no structural units responsible for quality management of education, such functions are additionally assigned to certain administrators, usually vice-rectors in charge of educational work or experts in methodology, who have a number of other functions, and therefore the process of internal quality assurance is of a formal nature, it is reduced to conducting rectoral tests and assessment analyses of the students' grades. The prevailing number $(86.0 \%)$ of medical schools and colleges note that the process of introducing the internal quality assurance system of educational activities requires the elaboration of the pattern of local quality assurance system that would take into account the uniqueness of a medical institution, would be adapted to the specifics of the medical school or college learning environment and would be made public in the form of methodical recommendations. The management of 20 medical schools and colleges (86\%) admit that the process of introducing internal quality assurance systems requires the creation of a certain model of a local quality assurance system.

Medical education institutions have taken on board the commitment to study of the interests and opinions of stakeholders (students, entrants, teachers, administration, governing bodies, students' parents, employers, professional and public organizations, etc.). However, even if there is a quality feedback from the stakeholders, in most cases, the obtained results are not taken into account when reviewing educational programs. The problem of quality and adequate response to the results of the quality audit of the existing educational programs is provided by the educational standard for training students in the field of health care is a unified qualifying exam and its component, namely the licensed comprehensive qualifying exam "KROK". The elimination of the "unnecessary" disciplines, the introduction of new compulsory disciplines, the expansion of the list of electives is not virtually realized in medical HEIs. The possible reason is that the State Institution "Testing Center at the Ministry of Health of Ukraine" forms the pool of test tasks on the basis of the estimated curriculum for the training of medical personnel. In doing so, the cycles of natural sciences and professional training are deemed obligatory.

Medical HEIs have elements in place for assessing the quality of teachers' work, but the results of such audits are closed and are not published on websites. In addition, the main activities carried out based on the results of the audit are 
individual interviews of the head and the teacher. Only $47.0 \%$ of medical colleges and schools out of 23 use the technological innovations in educational activities, which indicates the inadequacy of information and educational environments and the need for its introduction for both external and internal quality assurance system of the educational process, which was evidenced in the conditions of quarantine COVID-19.

An analysis of the official websites of medical schools and colleges gives the ground to conclude that most sites are overloaded with reports about activities and events at educational institutions, but they have minimum information for students, applicants and other stakeholders to ensure quality, content of educational programs and disciplines, as well as the evaluation criteria.

Taking a closer look at the effectiveness indicators of the quality assurance system, it should be noted that the correlations between the academic performance data indicate the systemic dependence of the of general and special competencies formation in students on managerial decisions on educational quality, pedagogical skills and awareness of the faculty, as well as commitment to the efficient management of HR, information, innovation, methodological, and financial resources.

\section{Conclusion}

Based on the findings of the study, we drew some conclusions about the state of the QMS and QA implementation in medical HEIs of Ukraine. With this current study, we determine that there is a discrepancy between the information on the implementation of internal quality assurance system declared by the management of medical colleges and schools; issues of ensuring the quality of educational activities are dealt with by officials at different levels of the management structure. The major issues to be addressed are: 1) a consistent coordination and monitoring of quality management; 2 ) the provision of quality feedback from the HEI to all stakeholders for reviewing the educational programs. It should be emphasized that the major recommendations for medical HEIs are to improve the management of educational activities, the implementation of the internal QA system, the monitoring of the key competencies, the quality feedback from stakeholders. In addition, the implementation of a QA model of educational activities at medical HEIs that train nurses, midwives, paramedics provides for the development of a consistent formation of the professional mindset. It is demonstrated by strong and medium direct correlation links between the competencies' formation in both fundamental and major disciplines in the educational programs. The data obtained during the study and analyzed and generalized results provided an opportunity to determine the state of the quality management system of educational activities in the training of health care professionals in Ukraine during 2014-2019.

\section{Limitations of the study}

The overriding limitation of this study was that even though medical HEIs have the tools for assessing the quality of teachers' work, the results of such audits are 
not in open access on websites. Another limitation was the scarcity of feedback from the stakeholders, the obtained feedback is not taken into account when reviewing educational programs majoring in nursing.

\section{Directions for future research}

Further research prospects may be monitoring studies of the effectiveness of quality assurance systems in Ukrainian HEIs in 2020-2021, in particular to find how the principles of total quality management are applied in comparison with the survey of 2014-2019, what best practices the HEI leaders benchmarked and adopted to assure quality; whether all relevant stakeholders such as students and employees are engaged in managing quality at the HEI.

\section{References}

Al-Ababneh, H., \& Alrhaimi, S. (2020). Modern Approaches to Education Management to Ensure the Quality of Educational Services. TEM Journal, 9(2), 770-778.

Bilokonenko, H. V. (2018). Tools for Designing, Monitoring and (Self)Evaluating the Efficiency of Internal Quality Assurance System by Hei. Adaptive Management: Theory and Practice. Series Pedagogics, 5(9).

Bucharest Communique. (2012). Making the Most of Our Potential: Consolidating the European Higher Education Area, Bucharest Communique 2012. Retrieved from http://www.ehea.info/Upload/document/ministerial_declarations/Bucharest _Communique_2012_610673.pdf

Camilleri, F. A. (2017). Standardizing Management Systems for Educational Organizations: Implications for European Higher Education, 12th European Quality Assurance Forum, Riga, Latvia.

Cumming, A. (2010). The Bologna process, medical education and integrated learning. Medical Teacher, 32(4), 316-318. https:// doi.org/10.3109/01421590903447716

Finikov, T. V., \& Tereschuk, V. I. (2018). Lokalni systemy upravlinnya yakistyu: svitovyi dosvid ta ukrayinski praktyky pobudovy [Local quality management systems international and Ukrainian practices]. Kyiv: Takson. Retrieved from http://www.edupolicy.org.ua/_dx/assets/images/Analit18ua_08-5mm.pdf

Fonseca, L. M. (2015). From quality gurus and TQM to ISO 9001:2015: a review of several quality paths, Int. J. Qual. Res., 9, 167-180.

Freedom of Education Index. (2016). Worldwide report 2016 on freedom of education. OIDEL: Fondazione Novae Terrae. Retrieved from http://oidel.org/doc/FEI_complet2.pdf

Future of Europe: Towards a European Education Area by 2025. (November 14, 2017). (Press Release) Retrieved from https://ec.europa.eu/commission/ presscorner/detail/en/IP_17_4521

Gordiichuk, S. V. (2017). Ensuring the quality of educational activities at the institutional level. Pedagogical sciences: a collection of scientific works, 139-144. (In Ukrainian).

Gordiichuk, S. V. (2018). Substantiation of internal quality assurance of educational activity and quality of higher education in Zhytomyr Medical Institute in the conditions of European higher school. Bulletin of Luhansk National University named after T. Shevchenko (Pedagogical sciences), 6(320), 103-110. (In Ukrainian).

Gordiichuk, S. V. (2019a). Management of the internal system of quality assurance of educational activities in medical education institutions. Bulletin of the National University "Chernihiv Collegium" named after T.G. Shevchenko, 5(161), 48-52. (In Ukrainian). 
Gordiichuk, S. V. (2019b). Management of the quality of educational activities of a medical educational institution on the basis of an innovative approach. Bulletin of Zhytomyr I. Franko State University, 2(97), 35-42. (In Ukrainian).

Johnson, D. (2019). Assessing Quality Assurance Practices in Institutions of Higher Learnings. International Journal of Learning, Teaching and Educational Research, 18(12), 30-45. https://doi.org/10.26803/ijlter.18.12.3

Karuppusami, G., \& Gandhinathan, R. (2006). Pareto analysis of critical success factors of total quality management: A literature review and analysis. The TQM Magazine, 18(4), 372-385. https://doi.org/10.1108/09544780610671048

Knutson, S., \& Kushnarenko, V. (2015). Ukraine: The New Reforms and Internationalization. International Higher Education, 79, 18-19. https://doi.org/10.6017/ihe.2015.79.5850

Kondrashov, N. (2018). Interaction of the higher education and school in the future teacher to continuing professional education. Indywidualistyczny $i$ wspolnotowy obraz ksztalcenia doroslych $w$ swiecie - terazniejszosc i perspektywy. Monografia wieloautorska; redakcja naukowa Leszek Ploch, Matgorzata Myszka, Aneta Nieweglowska, Malgorzata Wisniewska: Siedlce (pp. 139-147).

Kovtun, O., \& Stick, S. (2009). Ukraine and the Bologna Process: A Case Study of the Impact of the Bologna Process on Ukrainian State Institutions, Higher Education in Europe, 34(1), 91-103. https:// doi.org/10.1080/03797720902747066

Kuruch, A. V. (2018). Ensuring the quality of higher education in Ukraine: the challenges of today. Science and Education a New Dimension. Pedagogy and Psychology, VI(70)(170), 27-32. https:// doi.org/10.31174/SEND-PP2018-170VI70-06

London, N. A. (2006). The management of quality in education in an emergent society: a case study. Journal of Education Policy, 1(3), 303317. https://doi.org/10.1080/0268093960110303

Lubwama, J., Onen, D., \& Kasenene, E. S. (2017). Influence of Management on Quality Assurance in National Teacher's Colleges. International Journal of Learning, Teaching and Educational Research, 16(11), 138-156. https://doi.org/10.26803/ijlter.16.11.8

Macha, W. (2018). Incompatible With Bologna? The Two-Cycle Degree Structure in Medical Education in the EHEA. Education Policy, Dec. 11. Retrieved from https://wenr.wes.org/2018/12/two-cycle-degree-structure-in-medicaleducation-in-the-ehea

Martin, M. (2018). Internal Quality Assurance: Enhancing higher education quality and graduate employability. Paris: IIEP-UNESCO.

Mazurkiewicz, M. (2016). Quality Assurance in Higher Education Institutions in Ukraine 2016 through the prism of European Guidelines and Standards ESG 2015. Wrocław: EXANTE. Retrieved from http://quaere.pwr.edu.pl/wp-content/uploads/QAin-Ukraine-reports.pdf

Mazurkiewicz, M., Liuta, O., \& Kyrychenko, K. (2017). Internal Quality Assurance System for the Higher Education: Experience of Ukraine and Poland. Business Ethics and Leadership, 1(4), 74-83. https://doi.10.21272/bel.1(4).74-83.2017.

Mission and Strategy. (2020). The National Agency for Higher Education Quality Assurance (Ukraine). Retrieved from https:/ / en.naqa.gov.ua/?page_id=642

Oluwafemi, I., \& Laseinde, T. (2020). Useful Total Quality Management Critical Success Fundamentals in Higher Education Institution. Human Systems Engineering and Design, II, 1066-1074. https://doi.10.1007/978-3-030-27928-8_158.

Patrício, M., \& Harden, R. M. (2010). The Bologna Process - A global vision for the future of medical education. Med Teach, 32(4), 305-315. https://doi.org/10.3109/01421591003656123 
Psomas, E., \& Anthony, J. (2017). Total quality management elements and results in higher education institutions: The Greek case. Quality Assurance in Education, 25(2), 206-223. https://doi.org/10.1108/QAE-08-2015-0033

Sallis, E. (2015). Total Quality Management in Education (3rd Edition). Routledge.

Sari, Y., Hadiyat, M. A., \& Beatrice, C. (2015). The design and implementation of Lean Quality Management System National, Conference Proceedings of Production System XI and Quality Engineering Management, VI (pp. B123-B136).

Sciarelli, M., Gheith, M. H., \& Tani, M. (2020). The relationship between soft and hard quality management practices, innovation and organizational performance in higher education. The TQM Journal. https://doi.org/10.1108/TQM-01-2020-0014

Sila, I., \& Ebrahimpour, M. (2002). An investigation of the total quality management survey based research published between 1989 and 2000: A literature review. International Journal of Quality \& Reliability Management, 19(7), 902-970. https://doi.org/10.1108/02656710210434801

Standards and Guidelines for Quality Assurance in the European Higher Education Area. (2015). Kyiv: CS Ltd.

Strategy of the National Agency For Higher Education Quality Assurance to 2022. (2020) Retrieved from https://en.naqa.gov.ua/wpcontent/uploads/2020/04/Strategy-to-2020.pdf

Stukalo, N., \& Dluhopolskyi, O. (2020). Peculiarities of Educational Programs Accreditation in Pandemic Times (Case of Ukraine). Implementation of European Standards in Ukrainian Educational Research: Conference proceedings of the materials presented at the Forth UERA Conference, June 26, 2020. Drohobych: Trek.

Sydorenko, N. (2016). Internal quality assurance of higher education in Ukraine as social and educational priority. Public Administration and Local Government, 4(31), 81-86.

Tarí, J. J., \& Dick, G. P. M. (2016). Trends in quality management research in higher education institutions. Journal of Service Theory and Practice, 26(3), 34-70. https://doi.org/10.1108/JSTP-10-2014-0230

The European Higher Education Area in 2020: Bologna Process Implementation Report (2018). Retrieved from http://www.ehea.info/page-ministerial-conferenceparis-2018

Wibisono, E. (2018). The new management system ISO 21001:2018: What and why educational organizations should adopt? International Seminar on Industrial Engineering and Management, Makassar, Indonesia, 11. 


\section{Appendix 1}

Questionnaire

for heads or deputies for educational work (vice-rectors) of medical higher education institutions

Dear colleagues!

This questionnaire addresses the monitoring of the internal quality assurance system of education in medical colleges / institutes / academies. The results of the questionnaire will be used for scientific purposes to improve the quality management system of educational process.

1. Indicate the form of ownership of the HEI, which you head or in which you work (public or private).

2. Please name the management structures in the HEI that you head or in which you work.

3. Please indicate the number of teachers who work in your HEI (as the main employment).

4. Please indicate the number of teachers working in your HEI.

5. Please indicate the number of students studying in your HEI.

6. Does your educational institution have an internal quality assurance system?

7. Are there elements of the internal quality assurance system of education in your HEI?

8. Does the HEI you head or work in intend to establish an internal quality assurance system of educationalactivity? If not, what hinders your intentions?

9. Please indicate which elements of the internal quality assurance system of education (principles and procedures) are used in the HEI that you head or in which you work (please give one answer in each line):

9.1 ensuring the quality of educational programs;

9.2. ensuring the quality of teaching and assessment;

9.3. ensuring the quality of learning outcomes;

9.4. ensuring the quality of students' work.

10. What difficulties did the HEI, which you lead or work in, face in the process of implementing the internal system of quality assurance of education and/or its elements?

11. Please, name the main documents that regulate the functioning of the internal quality assurance system of education and its individual elements in the HEI, which you head or in which you work (regulations, orders of the rector, etc. (please specify)?

12. Has the HEI which you lead or in which you work, received a certificate certifying the compliance of the quality management system with the requirements of the international standard ISO 9001: 2015?

13. Do you carry out preparatory work to obtain a certificate proving compliance of the quality management system with the requirements of the international standard ISO 9001: 2015?

14. Is there a separate structural unit in the HEI that you head or work in that is responsible for managing the quality of education? 
1. Yes (Please indicate the name of the unit) (Please indicate the title of its head) (Indicate if this is a separate position) (Additional function of a certain administrator)

2. No.

15. Are the functions of quality management of education assigned to certain structural units of the HEI that you head or in which you work?

16. How were the interests and opinions of stakeholders / stakeholders studied when reviewing the set of educational programs (specialties)? (Please give one answer in each line):

16.1. students;

16.2. entrants;

16.3. faculty;

16.4. HEI administration;

16.5. management bodies of the HEI;

16.6. students' parents / entrants' parents ;

16.7. employers ;

16.8. professional, public associations, unions, agencies, etc.

17. What tools are used to audit / evaluate the quality of existing educational programs? (Please give one answer in each line):

(Systematically / Periodically / Not implemented / There was no need for implementation)

17.1. Ongoing surveys of students on the quality of educational programs in general;

17.2. Survey of students on the level of their satisfaction with the content of curricula;

17.3. Survey of employers on the quality of existing educational programs;

17.4. Creating an expert panel of professionals-practitioners in this field;

17.5. Evaluating the content of plans / programs with the help of graduates of this specialty / educational program;

17.6. Comparison of the content of educational programs with similar programs of Ukrainian HEIs;

17.7. Comparison of the content of educational programs with similar programs of foreign HEIs.

18. What activities are carried out in the HEI, which you head or in which you work, based on the results of the audit? (Please give one answer in each line)?

(Systematically / Periodically / Not implemented / There was no need for implementation)

18.1. removal of unnecessary disciplines

18.2. introduction of new compulsory disciplines

18.3. transfer of disciplines to another course

18.4. expansion of the list of elective disciplines

18.5. creation of new educational programs

19. Is there an audit / evaluation of the quality of teachers' work in the HEI that you head or in which you work?

1. Yes 2. No.

20. What tools are used in the audit / evaluation of the quality of teachers' work? (Please select one answer in each line)?

20.1. ongoing surveys of students on the quality of work of specific teachers; 
20.2. conducting open classes with their subsequent evaluation by teachers and administrators;

20.3. conducting final control in the discipline (test/exam) by another teacher;

20.4. rectoral tests;

20.5. assessment of the volume and quality of the educational and methodological support of the discipline developed by the teacher (textbooks / manuals, workshops, tests, etc.);

20.6. evaluation of scientific activity of the teacher (number of scientific publications, participation in scientific conferences, etc.) on issues of quality assurance of education;

20.7. assessment of extracurricular activity of the teacher (conducting competitions and contests, tutorials on students' research, etc.).

21. What actions are taken based on the results of the audit of teaching quality? (Please give one answer in each line):

(Systematically / Periodically / Not implemented)

21.1. interview with the head / rector;

21.2. publication of teachers' ratings

21.3. wage differentiation depending on the results of the quality audit;

21.4. awarding the best teachers;

21.5. obliging the teacher to pass advanced training courses, trainings, etc.;

21.6. dismissal of a teacher.

22. Is there an audit / evaluation of learning outcomes in the HEI you lead or work in?

1. Yes.

2. No.

23. What tools are used in the audit of learning outcomes? (Please give one answer in each line)?

(Systematically / Periodically / Not implemented)

23.1. Carrying out internal measurements of the level of competence formation (rector's control, internal testing, internal reviewing, etc.)

23.2. Carrying out external measurements of the level of formation of competencies (external review of the course / diploma, tests, etc.)

23.3. Receiving feedback from graduates on the application of the level of competencies

23.4. Receiving assessment from organizations and enterprises where graduates work, by means of feedback.

24. What measures are taken as a result of the audit of the quality of acquired professional (special) competencies of graduates of the institution? (Please give one answer in each line)?

(Systematically / Periodically / Not implemented / There was no need for implementation)

24.1. Considering to keep the educational program (speciality)

24.2. Analysis of the staff that provides teaching in this educational program (speciality)

24.3. Replacement of the head (curator) of the program (speciality)

25. What are the procedures for reviewing student complaints in the HEI that you head or in which you work? 
26. What documents regulate the procedures for reviewing the complaints of students in the HEI, which you head or in which you work?

27. Can the students' complaints in the HEI, which you head or in which you work, result in:

27.1. correction of the content of the educational program

27.2. correction of the content of the curriculum

27.3. replacement of a teacher

27.4. transferring the discipline from the curriculum (one year / several years later / earlier)

28. Does your HEI use an electronic environment for student learning (MOODLE, services and information tools, etc.)? (Please select one answer)?

1. Yes.

2. Not yet, but we are at the stage of choosing a system and its implementation.

3. No.

Date

Responsible for the survey:

Vice-Rector for Academic Affairs: Svitlana Gordiichuk.

Contact phone: (097) 2887464, e-mail: stepanovasvg77@gmail.com 